\title{
Institutional Performance of Irrigation System in Spatial Dimensions in Semi-Arid Region Timor Island East Nusa Tenggara
}

\author{
Ida Nurwiana ${ }^{1}$, Akhmad Fauzi ${ }^{2}$, Ernan Rustiadi ${ }^{3}$, Bambang Juanda ${ }^{4}$ \\ ${ }^{1}$ Faculty of Agriculture, Nusa Cendana University Penfui PO Box 104, Kupang 85001-East Nusa Tenggara, Indonesia \\ ${ }^{2,3,4}$ Regional and Rural Development Planning, Bogor Agricultural University (IPB) Darmaga Campus of IPB, Bogor 16680, \\ Indonesia
}

\begin{abstract}
Thirty-four percent (34.40\%) of irrigation areas in Indonesia are under the authority of the central government, $17.89 \%$ under the authority of the provincial government and $47.71 \%$ are under the authority of the District/Municipality government. Various efforts have been made by the government to improve the performance of surface water irrigation systems that cover $78 \%$ of the total irrigation area, however, the performance did not improve significantly. One of the cause is due to the damage of national surface water canals that affect the performance of the irrigation system. The purpose of this study was to analyze the factors that influence the institutional performance of the irrigation system in the spatial dimension in the semi-arid region of Timor Island, East Nusa Tenggara. The spatial approach of the Geographically Weighted Regression (GWR) method was chosen as an alternative approach in the analysis of irrigation system performance because it considers the variability of hydrogeological characteristics and the performance of different irrigation systems in each irrigation area based on their authority. The results of this study indicated that the total cropping intensity had a significant effectand decreased the performance of the irrigation system. The higher rice productivity and the maintenance frequency of the main system (headworks and canals) would improve the performance of the irrigation system. Meanwhile, the lower damage rate of the main system would improve the performance of the irrigation system. Irrigation area under the authority of district/municipality had a lower/worse irrigation system performance than those under the authority of provincial and central governments.
\end{abstract}

KEYWORDS: GWR, irrigation system institutions, irrigation system performance, semi-arid region

\section{INTRODUCTION}

The total irrigation area of Indonesia covered 9.136 .027 ha with $78.21 \%$ of surface water irrigation, $3.82 \%$ of the area was in the East Nusa Tenggara (NTT) province. Of the total irrigation area, 406 irrigation area accounted for 3.142 .532 ha (34.40\%) under the authority of the central government of the Republic of Indonesia, and 3.4\% were in the NTT province. 1.296 of the irrigation area covered 1,634,467 ha (17.89\%) under the authority of the provincial government, $3.69 \%$ in the NTT province and 54.589 irrigation area with 4.359 .028 ha $(47.71 \%)$ under the authority of the district government, $4.33 \%$ are in the NTT province (Data of The Ministry of Public Works and

Housing/PUPR). The irrigation area produced rice with an average productivity of 5.24 tons/ha with low productivity category. The low productivity is caused by the damage of surface water irrigation canals under the authority of the central government covering primary, secondary and waster irrigation canals. The irrigation canals condition in 2010 compared to rehabilitated canals in 2015 showed a very significant change; categorized good for irrigation canals under the authority of the central government, moderate for irrigation canals under the authority of the provincial government. However, the irrigation area of the district/municipality authority occurred anomalies, where good irrigation canals decreased from $48 \%$ to $40.95 \%$ and damaged irrigation canals increased from 52\% to 59.05\% (Ministry of Public Works and Housing/PUPR). This condition is an indication that the performance of the irrigation system has decreased.

The performance of irrigation systems as a unified system is a very complex aspect, which includes the availability of irrigation water, irrigation areas, irrigation infrastructure (head works and canals), human resources, irrigation institutions (distribution of irrigation area authority), management, supporting facilities of irrigation, financing, technology, participation of farmers / water user's association (WUA). These components interrelated each other to provide, regulate, dispose of excess water in 


\section{International Journal of Current Science Research and Review}

ISSN: 2581-8341

Volume 04 Issue 06 June 2021

DOI: 10.47191/ijcsrr/V4-i6-15, Impact Factor: 5.825

IJCSRR@ 2021

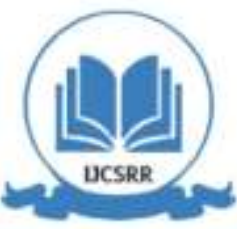

www.ijesrr.org

supporting agricultural activities and maintain productivity increases. Thus, many indicators effect the performance of irrigation systems.

Various indicators are used to assess the performance of irrigation systems such as availability/discharge of water and adequacy of irrigation water, [1,2,3,4,5,6,7], regularity, accuracy, distribution of irrigation water [8,1,9,10,11], and effectiveness of irrigation water $[9,10]$. Water availability may increase crop intensity $[12,9,3,13,14]$ and productivity $[$ Kalu et al. in 5,9,10,15,6], which affected the performance index of the irrigation systems.

Infrastructure of Irrigation including headworks and irrigation canals (primary, secondary, drainage) supports the irrigation systems, as tappers and distributors to carry irrigation water into irrigated land which is reflected by the efficiency of irrigation water $[1,9,11,5$,$] . Meanwhile, sustainability of infrastructure usage is dependent on maintenance capabilities [16], the quantity of$ maintenance [9], financing of operations and other maintenance indicators impact on the performance of irrigation systems. Likewise, maintenance also requires the participation of P3A (WUA) [17, Bhatta et al. in 18,19,20] to maintain and improve irrigation efficiency. The performance of a good irrigation system is also related to institutional aspects; the regulation of the division of authority in irrigation areas which includes the district, provincial and central government authority areas for managing the irrigation system as stated in the PUPR role number 14/PRT/M/2015 concerning Criteria and Determination of Irrigation Area Status. The importance of institutional aspects in assessing the performance of irrigation systems has been reported in previous studies, [21,2,3,22,23,24,25,26,27].

Efforts to reduce the damage rate of irrigation canals have been carried out by the government, however, this enable to reduce the damage of irrigation canals, especially the irrigation canals under the authority of district/municipality government. This condition might be caused by the efforts to reduce the damage which are considered the same without considering hydrogeology, climate or spatial aspects. According to the study of [22,23] differences in hydrogeological factors between locations/regions can explain the institutional variation between regions and the spatial distribution of water, thus, the performance of irrigation institutional systems in areas with abundant water should be different from areas with insufficient water. Therefore, the use of geographical disaggregation techniques is possible to find out the factors that effect the performance of irrigation systems at the lowest level and expected to provide a broad conclusion of the variation in irrigation system performance based on the characteristics of the dry area and the institutional authority of each irrigation area.

The importance of spatial analysis is based on Tobler's first law on geography in

[28] that everything is related to each other where something close has a greater effect than that is far away. Spatial analysis by [29] is also used to overcome issues in the difficult use of global methods in showing spatial heterogeneity with limited interpretation and issues that not show regional effect. Therefore, the results of an accurate analysis of the performance of the irrigation system must include the spatial aspects in the analysis to describe the irrigation area in a specific location. Various studies have shown the utility of Geographically Weighted Regression (GWR) analysis, to investigate various types of scientific fieldssuch as: climatology problems [30], ecological inference problems [31], urban poverty [32], environmental justice [33], the relationship of population density with house value [34], the relationship between vegetation and climate [35], relationship between agricultural productivity, cropping intensity and relative irrigation impacts [14], yields of maize and soybean plants with irrigated lands [36], factors that effect the efficiency of irrigation water use [37] and unemployment rate [38].

The objective of this study was to analyze the factors that effect the performance of site-specific irrigation systems in irrigated areas under the authority of district/municipality, provinces and the central government of the Republic of Indonesia in the dry regions of Timor Island with GWR method. This research is expected to give consideration in policy making by local governments in the dry regions of Timor Island in handling irrigation systemm performance by considering the location of irrigation areas characteristics so that efforts to handle the irrigation system performance become more effective and efficient.

\section{MATERIALS AND METHODS}

This study used secondary data from 345 irrigated areas on Timor Island NTT, covering 6 districts/cities, namely Kupang municipality, Kupang District, Timor Tengah Selatan (TTS) District, Timor Tengah Utara (TTU) District, Belu District, and Malaka District. The dependent variable used is the performance index of irrigation systems from 345 irrigated areas (Table 1). The study used global regression analysis with estimation of ordinary least square (OLS), dependency test using Moran's test and GWR for spatial model analysis. 


\section{International Journal of Current Science Research and Review}

ISSN: 2581-8341

Volume 04 Issue 06 June 2021

DOI: 10.47191/ijcsrr/V4-i6-15, Impact Factor: 5.825

IJCSRR@ 2021

www.ijcsrr.org

Table 1. Independent Variabel

\begin{tabular}{|c|c|c|}
\hline \multicolumn{2}{|r|}{ Variable } & Operational Definition \\
\hline $\mathrm{X}_{1}$ & Irrigation area & Total irrigation area (hectare) \\
\hline $\mathrm{X}_{2}$ & Cropping intensity & Total cropping intensity $(\%)$ \\
\hline $\mathrm{X}_{3}$ & Productivity & Productivity of rice (ton per hectare) \\
\hline $\mathrm{X}_{4}$ & Condition of headworks & Damage rate of headworks $(\%)$ \\
\hline $\mathrm{X}_{5}$ & Condition of primary canals & Damage rate of primary canals $(\%)$ \\
\hline $\mathrm{X}_{6}$ & Condition of secondary canals & Damage rate of secondary canals $(\%)$ \\
\hline $\mathrm{X}_{7}$ & Condition of drainage system & Damage rate of drainage system $(\%)$ \\
\hline $\mathrm{X}_{8}$ & Participation of WUA & $\begin{array}{l}\text { Participation rate of WUA in maintenance } \\
\text { primary and seconday canals }(\%)\end{array}$ \\
\hline $\begin{array}{l}\mathrm{S} \\
\mathrm{M} \\
\mathrm{m}\end{array}$ & $\begin{array}{l}\text { Supporting facilities for } \mathrm{O} \& \\
\mathrm{M} \text { (operational and } \\
\text { maintenance) }\end{array}$ & Availability of supporting facilities for O \& $\mathrm{M}(\%)$ \\
\hline $\mathrm{X}_{10}$ & Labor for $\mathrm{O} \& \mathrm{M}$ & Ratio of labor for $\mathrm{O} \& \mathrm{M}$ towards total irrigation area \\
\hline $\mathrm{X}_{11}$ & $\begin{array}{l}\text { Maintenance frequency of } \\
\text { main system }\end{array}$ & Maintenance frequency of main system (times per year) \\
\hline $\mathrm{X}_{12}$ & $\mathrm{O} \& \mathrm{M}$ cost & $\mathrm{O} \& \mathrm{M}$ cost (million Rp per year) \\
\hline $\mathrm{X}_{13} \quad \mathrm{R}$ & Rehabilitation cost & Rehabilitation cost (million Rp) \\
\hline $\mathrm{DK}_{\mathrm{k} / \mathrm{k}}$ & $\begin{array}{l}\text { Institutional authority of } \\
\text { irrigation system }\end{array}$ & $\begin{array}{l}\text { Dummy variable authority of irrigation area } \\
1=\text { District/Municipality }\end{array}$ \\
\hline $\mathrm{DK}_{\text {prov }}$ & $\begin{array}{l}\text { Institutional authority of } \\
\text { irrigation system }\end{array}$ & $\begin{array}{l}0=\text { others of Dummy variable authority of irrigation area } \\
1=\text { Provincial } \\
0=\text { others }\end{array}$ \\
\hline
\end{tabular}

OLS Multiple Linear Regression Analysis with the model:

$$
Y_{i}=\beta_{0}+\beta_{1} X_{1}+\beta_{2} X_{2}+\beta_{3} X_{3}+\beta_{4} X_{4}+\beta_{5} X_{5}+\beta_{6} X_{6}+\beta_{7} X_{7}+\beta_{8} X 8+\beta_{9} X_{9}+\beta_{10} X_{10}+\beta_{11} X_{11}+\beta_{12} X_{12}+\beta_{13} X_{13}+\beta_{14} D K_{k / k}+\beta_{15} D K_{\text {prov }}+
$$

Equation model 1 was estimated using OLS, classic assumption test, then the spatial effect test includes Moran's test and spatial heterogeneity test.

Moran's test (autocorrelation test) with the hypothesis:

$\mathrm{H}_{0}: I=0$ (there is no autocorrelation between locations)

$\mathrm{H}_{1}: I=0$ (there is autocorrelation between locations)

Autocorrelation occurs between locations when $\left|Z_{\text {hitung. }}\right|>$ Z $\alpha / 2$

$$
Z_{\text {hitung }}=\frac{I-\mathrm{EI}}{\sqrt{\operatorname{var}(\mathrm{I})}} \sim N(0,1)
$$




\section{International Journal of Current Science Research and Review}

ISSN: 2581-8341

Volume 04 Issue 06 June 2021

DOI: 10.47191/ijcsrr/V4-i6-15, Impact Factor: 5.825

IJCSRR@ 2021

Www.ijcsrr.org

Where $I$ is the Moran Index coefficient, E (I) is the expected value of the Moran Index, and var (I) is the variance of the Moran Index. Hypothesis H0 will reject the initial hypothesis when the value $|\mathrm{Zvalue}|>\mathrm{Z}(\alpha / 2)$ or reject $\mathrm{H} 0$ if the $\mathrm{p}$-value $<\alpha$. Identification of spatial patterns using index value criteriaI; $I>\mathrm{E}$ (I) suggests clustered pattern and $I<\mathrm{E}$ (I) has a diffuse pattern. E (I) is the expected value of I with $(I)=-1 /(n$

- 1) [39].

Breusch-Pagan heterogeneity test with the hypothesis:

$\mathrm{H}_{0}: \sigma_{1}^{2}=\sigma_{2}^{2}=\ldots .=\sigma_{\mathrm{n}}^{2}=\sigma^{2}$ (Homoskedasticity)

$\mathrm{H}_{1}$ : at least one $\sigma_{\mathrm{i}}^{2} \sigma^{2}$ (Spatial heteroskedasticity)

Statistics test is as follows:

$$
B P=\frac{1}{2} f^{T} \mathbf{A}\left(\mathbf{A}^{\mathbf{T}} \mathbf{A}\right)^{-1} \mathbf{A}^{T} f \sim \chi_{k}^{2}
$$

With $f$ vector elements is:

$$
f_{i}=\left(\frac{e_{i}^{2}}{\sigma^{2}},-1\right)
$$

Where:

$e_{i}=$ error of the OLS method for the $i$-th observation,

$\mathrm{A}=$ matrix with $n^{\mathrm{x}(k+1)}$ with a standard vector for each observation

The conclusion of reject $\mathrm{H}_{0}$ when $\mathrm{BP}>\chi_{k}^{2}$ orp-value $<\alpha$.

If the results of the spatial heterogeneity test in the OLS model show spatial heterogeneity, then alternative GWR modeling is needed; the GWR model is a global regression model that is converted into a weighted regression model. Each model parameter value is calculated at each geographic location point so that each geographic location point has different regression parameter values [29]. The basic formula for the GWR model is:

$$
y_{i}=\beta_{0}\left(u_{i}, v_{i}\right)+\sum_{k=1}^{p} \beta_{k}\left(u_{i}, v_{i}\right) x_{i k}+\varepsilon_{i}
$$

$k=1$

$y_{i} \quad$ : observation value for the response variable of $i$-th irrigation area

$(i=1,2, \ldots, 345)$

$x_{i k} \quad$ : observation value for the k predictor variable in $i$-th irrigation area

$(i=1,2,345)$

$\left(u_{i}, v_{i}\right) \quad$ : coordinate point (latitude,longitude) of i-th irrigation area (for water resources)

$\beta_{0}\left(u_{i}, v_{i}\right):$ GWR intercept

$\beta_{k}\left(u_{i}, v_{i}\right): k$ regression coefficient for $i$-th irrigation area

$\varepsilon_{i} \quad$ : errors assumed to be identical, independent, and normally distributed with zero averages and constant variances of $\sigma^{2}$

The GWR model requires a weighting matrix (W) that shows the distance between locations; this research used kernel's standard weight. The method used to select the optimum bandwidth is cross-validation $(\mathrm{CV})$ method;

$$
C V=\sum_{i=1}^{n}\left[y_{i}-\widehat{y}_{* i}(b)\right]^{2}
$$

Where:

$\hat{y_{\neq}}(b)$ : The estimated value of the regression model without $\mathrm{i}$-th observation $\mathrm{i}: i$-th location

b : bandwith 


\section{International Journal of Current Science Research and Review}

ISSN: 2581-8341

Volume 04 Issue 06 June 2021

DOI: 10.47191/ijcsrr/V4-i6-15, Impact Factor: 5.825

IJCSRR@ 2021

www.ijesrr.org

\section{RESULTS}

The OLS model estimation shows 15 variables which allegedly effect the performance of irrigation systems, Total irrigation area, Total cropping intensity, the productivity of rice, damage rate of primary canals, damage rate of secondary canals, damage rate of the drainage system, participation rate of WUA in maintenance primary and secondary canals, availability of supporting facilities for Operation and maintenance $(\mathrm{O} \& \mathrm{M})$, ratio of labor for $\mathrm{O} \& \mathrm{M}$ towards total irrigation area, maintenance frequency of main system (headwork and canals), $\mathrm{O} \& \mathrm{M}$ cost, Rehabilitation cost, Dummy variable of irrigation system institution for district/municipality. There are 7 (seven) variables significantly affect the performance of the irrigation system, indicated by the pvalue $<0.01$ and $<0.05$ with a determination coefficient $\left(\mathrm{R}^{2}\right)$ of 0.5831 ; suggested $58.31 \%$ variation in irrigation system performance is able to be explained by variables in the model (Table 2 ).

Table 2. The results of the global regression model (all variables and stepwise methods)

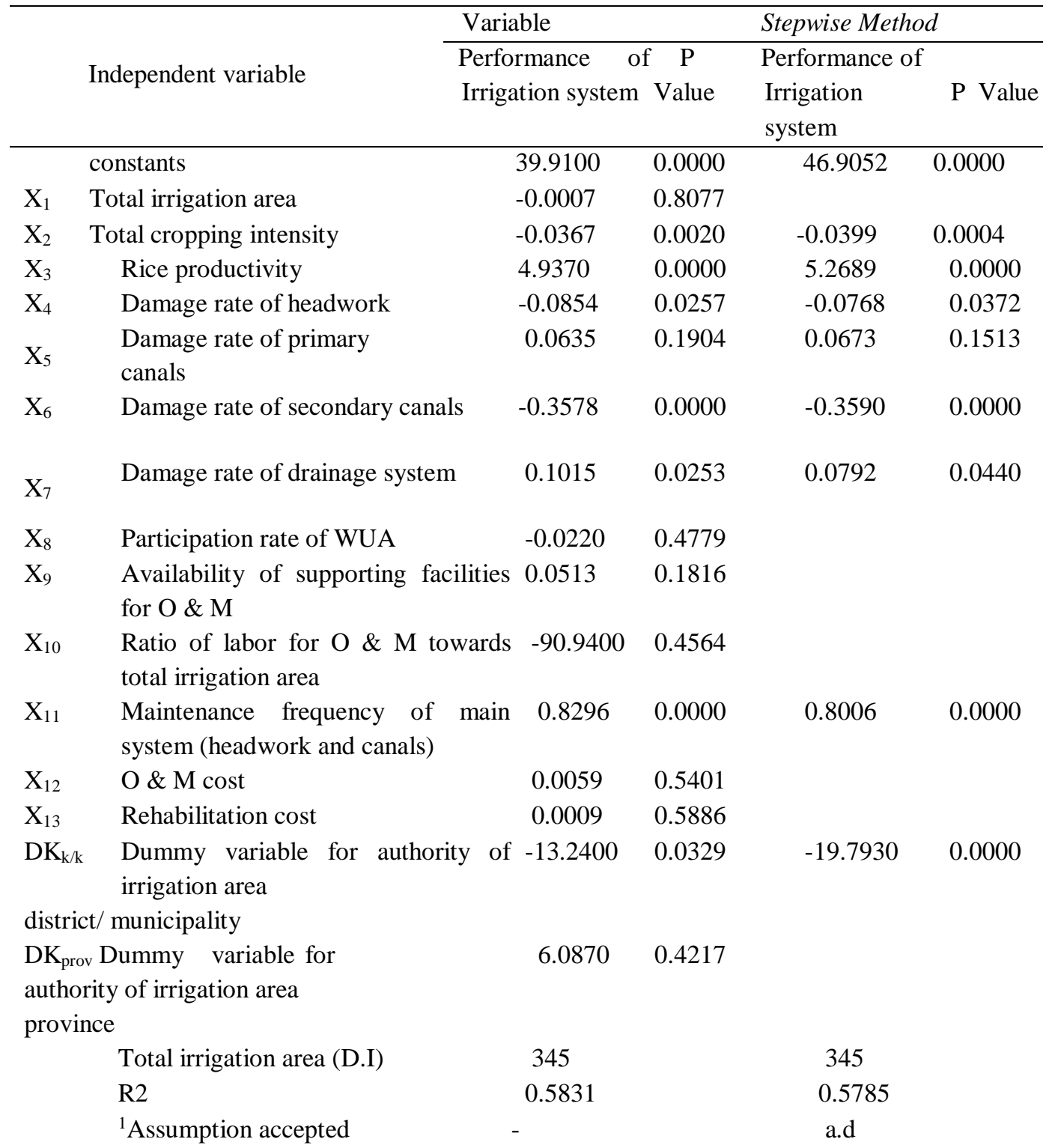

${ }^{1}$ residual assumption: a. normal distribution, b. homogeneous, c. independent, d. not multicollinearity 


\section{International Journal of Current Science Research and Review}

ISSN: 2581-8341

Volume 04 Issue 06 June 2021

DOI: 10.47191/ijcsrr/V4-i6-15, Impact Factor: 5.825

IJCSRR@ 2021

www.ijcsrr.org

Residual assumptions test on 15 variables showed a high risk of multicollinearity between the variable of total irrigation area $\left(\mathrm{X}_{1}\right)$ and operating and maintenance costs $\left(\mathrm{X}_{12}\right)$ with autocorrelation between observational data, residual heteroscedasticity with an abnormal distribution. The failure of these assumptions indicated the need for an alternative model, namely the regression of the stepwise method as shown in Table 2.

The stepwise OLS model estimation shows 7 out of 8 variables significantly effect the performance of irrigation systems, namely: total cropping intensity, the productivity of rice, damage rate of head works, damage rate of primary canals, damage rate of secondary canals, damage rate of the drainage system, maintenance frequency of main system (irrigation building and canals), dummy variable of irrigation system institution for district/municipality. These variables have significant positive and negative effects on the performance of irrigation systems, indicated by the p-value $<0.01$ and $<0.05$ with a coefficient of determination $\left(\mathrm{R}^{2}\right)$ of 0.79315 (Table 2). The results of the residual assumption in the stepwise model regression indicated the existence autocorrelation between the observed variables and heteroscedasticity, this proofed spatial aspects cannot be ignored in assessing factors effecting the performance of irrigation systems in each irrigation system. It is also proven by the spatial test which shows heteroscedasticity and spatial autocorrelation with the Moran's index value of 0.321550029 . The standard weight used Fixed Kernel with the Gaussian Kernel. The bandwidth value obtained was 0.2817266 on cross-validation 15540.23 . The stepwise model regression is used as an analysis of the GWR model as shown in Table 3 (The estimation results of the GWR parameter model on factors that effect the performance of irrigation system).

Table 3. The result of parameter estimation using GWR model on factor affecting the performance of irrigation system in dry region of Timor Island

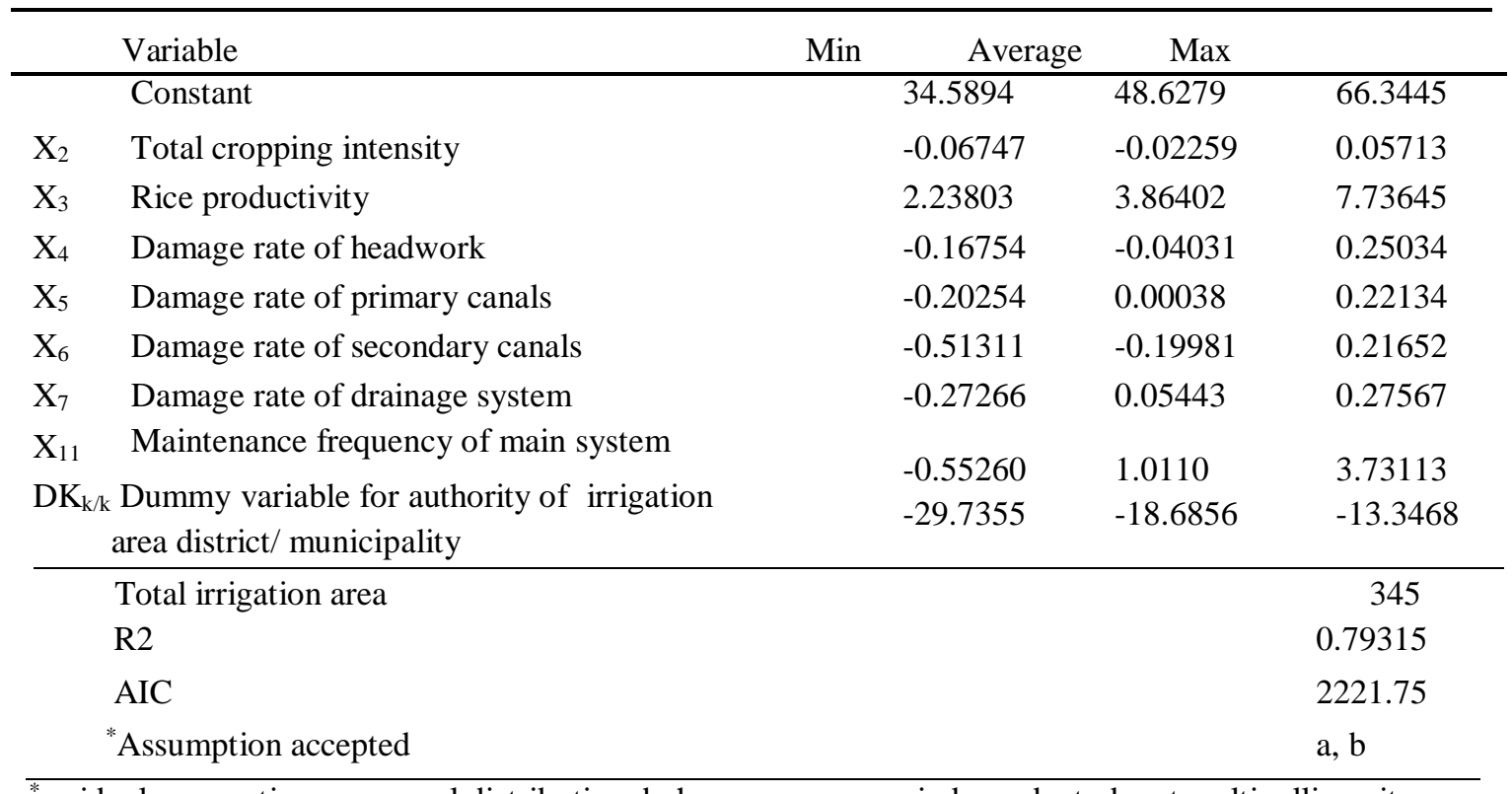

*residual assumption: a. normal distribution, b. homogeneous, c. independent, d. not multicollinearity

GWR Estimation model on the factors that effect the performance of the irrigation system shows that the independent variable response varies in each irrigation area region. These results proved that spatial aspects cannot be ignored due to the presence of hydrogeological characteristics between the irrigation areas/between regions. Therefore, in assessing the problems of irrigation systems, it is necessary to pay attention to the hydrogeological variability between the regions/locations of irrigation areas [23]. The variability is not only the physical factors of climate, water, infrastructure, but also the variability of the community in the farming system that adapt to the surrounding natural conditions. The dry climate affects the irrigation system as a whole, including the performance of the irrigation system. 


\section{International Journal of Current Science Research and Review}

ISSN: 2581-8341

Volume 04 Issue 06 June 2021

DOI: 10.47191/ijesrr/V4-i6-15, Impact Factor: 5.825

IJCSRR@ 2021

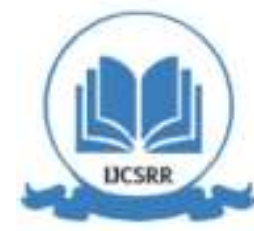

www.ijcsrr.org

Table 4 shows that the total cropping intensity variable had a significant effect on reducing the performance of the irrigation system, so that no one irrigation area is in accordance with the hypothesis. Meanwhile, the productivity of rice significantly improved the performance of irrigation systems both for irrigation areas of district/municipality, provincial and central government institutional authority. The irrigation infrastructure especially the damage rate of secondary irrigation canals had the most negative effect on the performance of the irrigation system with 73.62 percent; the higher damage rate of secondary irrigation canals might reduce the performance of irrigation systems. Furthermore, damage of the headwork of which 42.32 percent of the irrigation area had a significant negative effect on the performance of the irrigation system. Moreover, the damage rate of drainage canals with 28.70 percent and 21.16 percent for that in primary irrigation canals had a significant negative effect on the performance of irrigation systems. Buildings and irrigation canals were a problem for the territory of Timor Island in particular and NTT in general, with a dry climate, conditions for maintaining irrigation infrastructure, triggering the rate of damage to irrigation infrastructure faster than the rate of rehabilitation. While the frequency of maintenance 33.91 percent of the irrigation area had a significant and positive effect on the performance of the irrigation system and 100 percent of the irrigation area of the district/municipality had a significant and negative effect on the performance of the irrigation system. This means that the irrigation under the authority of the district/municipalityhad a lower/worse the performance of the irrigation system compared to the irrigation area of the provincial and central government authority. The spatial diversity of each variable and each irrigation area based on their authority in detail described as follows;

Table 4. The number of significant variable coefficients based on the hypothesis according to the authority of irrigation area district/ municipality, province, and central governments

\begin{tabular}{|c|c|c|c|c|c|c|c|c|}
\hline \multirow{3}{*}{ Variable } & \multicolumn{6}{|c|}{ Institutional authority of irrigation system } & \multirow{3}{*}{$\begin{array}{l}\text { Total } \\
\text { Irrig. } \\
\text { area }\end{array}$} & \multirow{3}{*}{$\%$} \\
\hline & \multicolumn{2}{|c|}{$\begin{array}{c}\text { District/ } \\
\text { Municipality }\end{array}$} & \multicolumn{2}{|c|}{ Province } & \multicolumn{2}{|c|}{$\begin{array}{c}\text { Central } \\
\text { Goverment }\end{array}$} & & \\
\hline & total $^{*}$ & $\%$ & total $\left.^{*}\right)$ & $\%$ & total $\left.^{*}\right)$ & $\%$ & & \\
\hline Total cropping intensity ${ }^{1)}$ & - & & - & & - & & - & \\
\hline Rice productivity ${ }^{1)}$ & 321 & 100 & 14 & 100 & 10 & 100 & 345 & 100 \\
\hline Damage rate of headwork ${ }^{2)}$ & 138 & 42.99 & 5 & 35.71 & 3 & 30 & 146 & 42.32 \\
\hline Damage rate of primary canals ${ }^{2)}$ & 70 & 21.81 & 1 & 7.14 & 2 & 20 & 73 & 21.16 \\
\hline Damage rate of secondary canals ${ }^{2}$ & 242 & 75.39 & 6 & 42.86 & 6 & 60 & 254 & 73.62 \\
\hline Damage rate of drainage system $^{2)}$ & 88 & 27.41 & 7 & 50.00 & 4 & 40 & 99 & 28.70 \\
\hline $\begin{array}{l}\begin{array}{l}\text { Maintenance frequency of main } \\
\text { system }^{1)}\end{array} \\
\end{array}$ & 111 & 34.58 & 5 & 35.71 & 1 & 10 & 117 & 33.91 \\
\hline $\begin{array}{l}\text { Dummy variable for } \\
\text { authority of irrigation area district/ } \\
\text { municipality }{ }^{2)}\end{array}$ & 321 & 100 & 14 & 100 & 10 & 100 & 345 & 100 \\
\hline Total irrigation area & 321 & & 14 & & 10 & & 345 & \\
\hline
\end{tabular}

Source: Estimation result. 2020

${ }^{*}$ significantly different at 0.01 and 0.05 level

1) Total and percentage of irrigation areas with positive coefficients

2) Total and percentage of irrigation areas with negative coefficients

\subsection{Total cropping intensity}

The total cropping intensity had a significant effect and a negative relationship to the performance of the irrigation system. Table 4 shows that there is no irrigation area with a positive effect on the performance of the irrigation system as the hypothesis 


\section{International Journal of Current Science Research and Review}

ISSN: 2581-8341

Volume 04 Issue 06 June 2021

DOI: 10.47191/ijesrr/V4-i6-15, Impact Factor: 5.825

IJCSRR@ 2021

Www.ijcsrr.org

proposed. Figure 1 shows the significance of the total cropping intensity variable on the performance of the irrigation system with a negative relationship. This means that the intensity of cropping increases the performance of the irrigation system. Timor Island is a dry region with limited water availability. An increase in crop intensity from the initial design of irrigation area planning can disrupt the whole irrigation system. Ideally the total cropping intensity is 300 percent with the 'rice-rice-secondary crop' or 'ricesecondary crop-secondary crop' cropping pattern, but in reality it can not be realized, as the availability of water and the ability of farmers. On the other hand, water is found to be sufficient but the limited labor, so the irrigated land cannot be planted entirely. Therefore, the increase in total cropping intensity for dry areas, in the case of water factors is an obstacle, will disrupt theperformance of the irrigation system. This condition may be the cause of negative relations between variables.

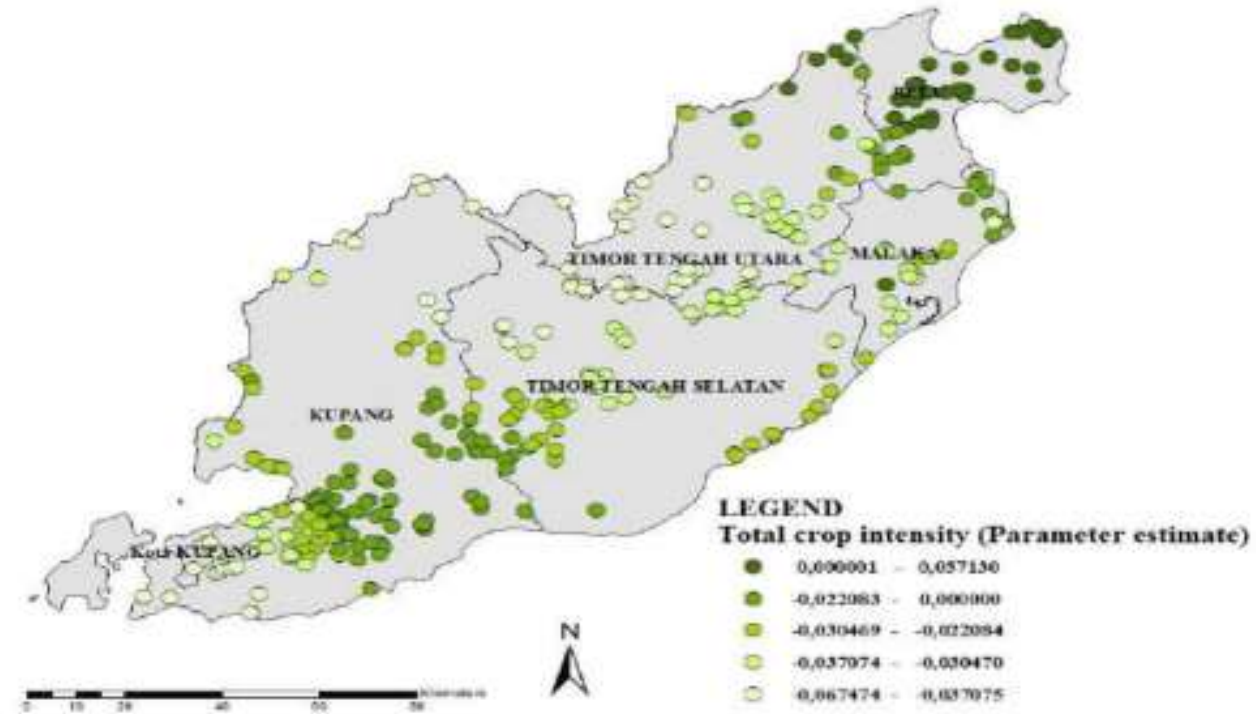

(1a)

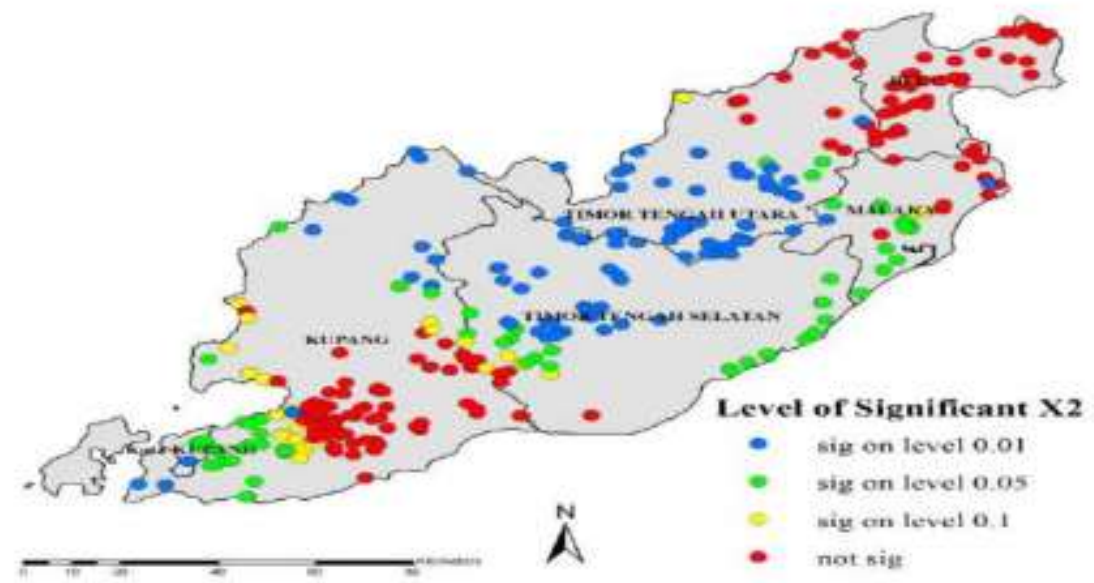

(1b)

Figure 1. (1a), (1b) Total cropping intensity and the significance of relationship between total cropping intensity and the performance of irrigation system 


\section{International Journal of Current Science Research and Review}

ISSN: 2581-8341

Volume 04 Issue 06 June 2021

DOI: 10.47191/ijcsrr/V4-i6-15, Impact Factor: 5.825

IJCSRR@ 2021

www.ijcsrr.org

Figure 1 shows the total cropping intensity significantly and negatively effects the performance of the irrigation system. Grouping in the middlenamely TTS, TTU, part of Malaka and part of Kupang municipality, covering 50.78 percent of district/municipality irrigation area. 35.71 percent of the irrigation area under the authority of the provincial institution and 30 percent of the irrigation area under the authority of the central government of Republic of Indonesia. This finding contrasts with the results of [13] study in the Shina-Hamusit Ethiopia irrigation area which suggested that planting intensity had a positive relationship effecting the performance of the irrigation system and causing the sustainability of irrigated land. In addition, the results of the [14] study also showed a positive relationship with the performance of the irrigation system. Furthermore, the increase in crop intensity was possible realized by the improvement of better irrigation facilities. Gwarda [38] in the irrigation area of Barugbug. Karawang Regency and Subang, concluded that one of the factors that effect the performance of irrigation systems is the total cropping intensity and crop productivity.

\subsection{Productivity of rice}

Rice productivity is the final product which is expected to always increase with the presence of irrigation. The results of this study indicated that rice productivity in all irrigated areas under the authority of districts/cities, provinces, central governments have a positive and significant relationship to the performance of irrigation systems (Figure 2). This means that the increase in rice productivity had an effecton improving the performance of irrigation systems. This result is in line with [Kalu et al. in 5,15,40,41]. Balderama et al. [6] in the Philippines, concluded that agricultural and economic productivity based on output per unit of irrigation area is one of three indicators (operating services system. agricultural and economic productivity. and finance) that determine the performance of irrigation systems. While [36] concluded that the diversity of crop productivity in each location was different due to differences in irrigation systems and also related to rainfall intensity. Although rice productivity in Timor Island is relatively low compared to potential yields, the community continues to grow rice to meet food needs and sometimes sold to meet other needs, instead of consuming more corn.

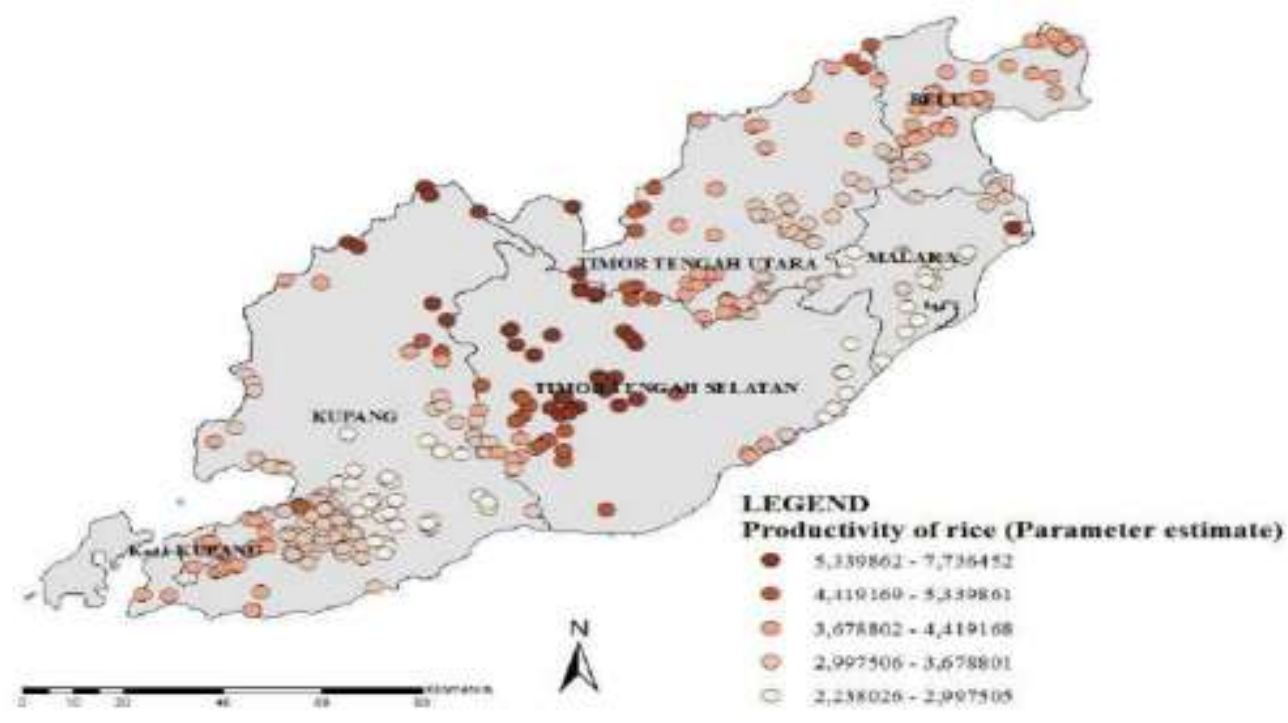

(2a) 


\section{International Journal of Current Science Research and Review}

ISSN: 2581-8341

Volume 04 Issue 06 June 2021

DOI: 10.47191/ijcsrr/V4-i6-15, Impact Factor: 5.825

IJCSRR@ 2021

www.ijjcsrr.org

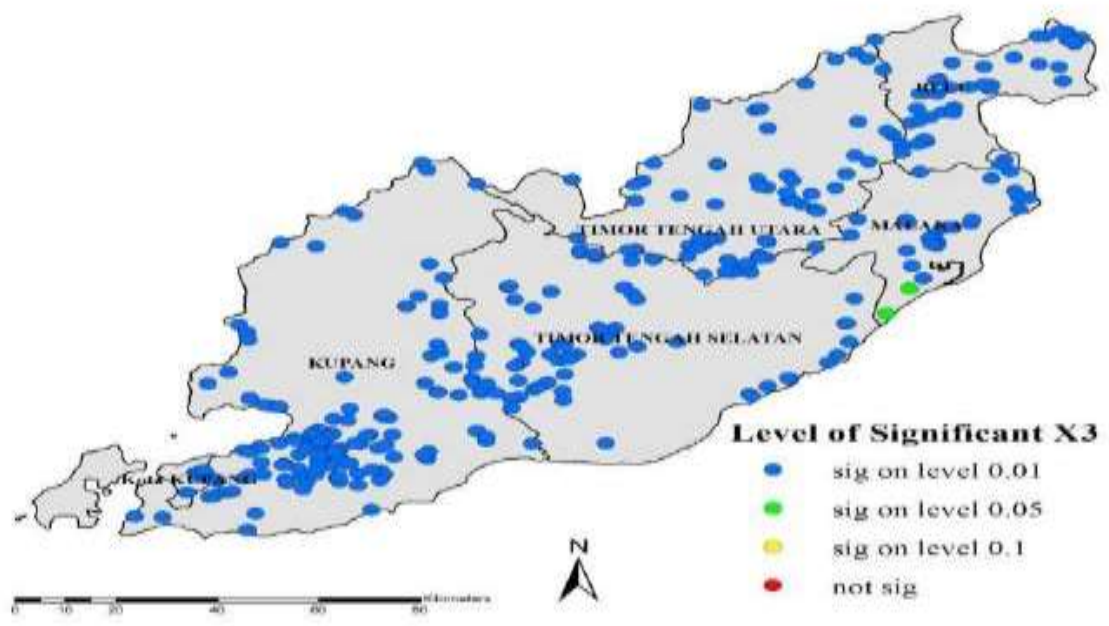

(2b)

Figure 2 (2a), (2b) Productivity of rice and the significance of relationship between productivity of rice and the performance of irrigation system

\subsection{Damage rate of headworks}

The results of the study showed that the damage rate of headworks had a significant effect and a negative relationship with the performance of the irrigation system (Figure 3). This means that the lower the damage level the headwork, the better the performance of the irrigation system. Irrigation areas in Kupang District and TTS District, covering 42.99 percent of the irrigation area of the district/municipality authority. 35.71 percent of the irrigation area of the provincial authority and 30 percent of the irrigation area of the central government authority. Although irrigation in NTT has been developed for a long time,headwork are relatively limited with the damage rate of irrigation infrastructure faster than that of rehabilitation. This is caused by dry climatic conditions which caused the water structures to break quickly, siltation, sedimentation, and lead to disruption of water distribution. The condition is also supported by limited maintenance frequency.

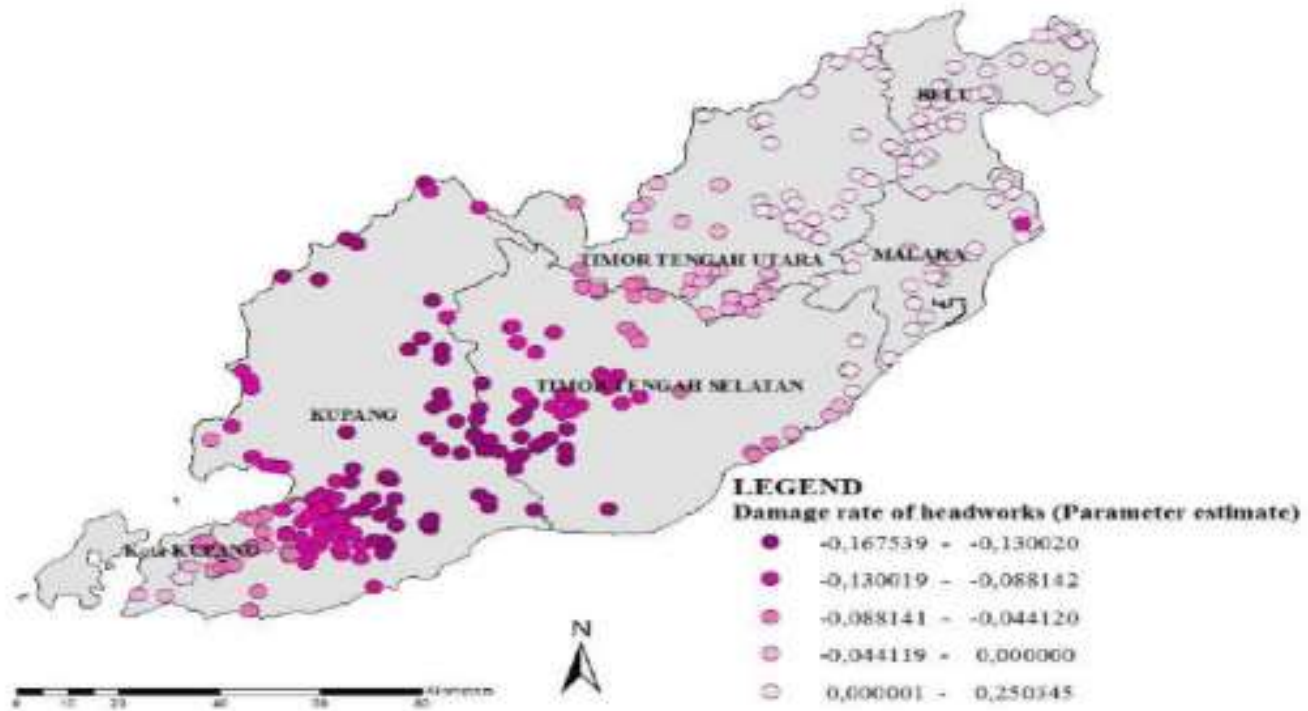

(3 a) 


\section{International Journal of Current Science Research and Review}

ISSN: 2581-8341

Volume 04 Issue 06 June 2021

DOI: 10.47191/ijcsrr/V4-i6-15, Impact Factor: 5.825

IJCSRR@ 2021

www.ijcsrr.org

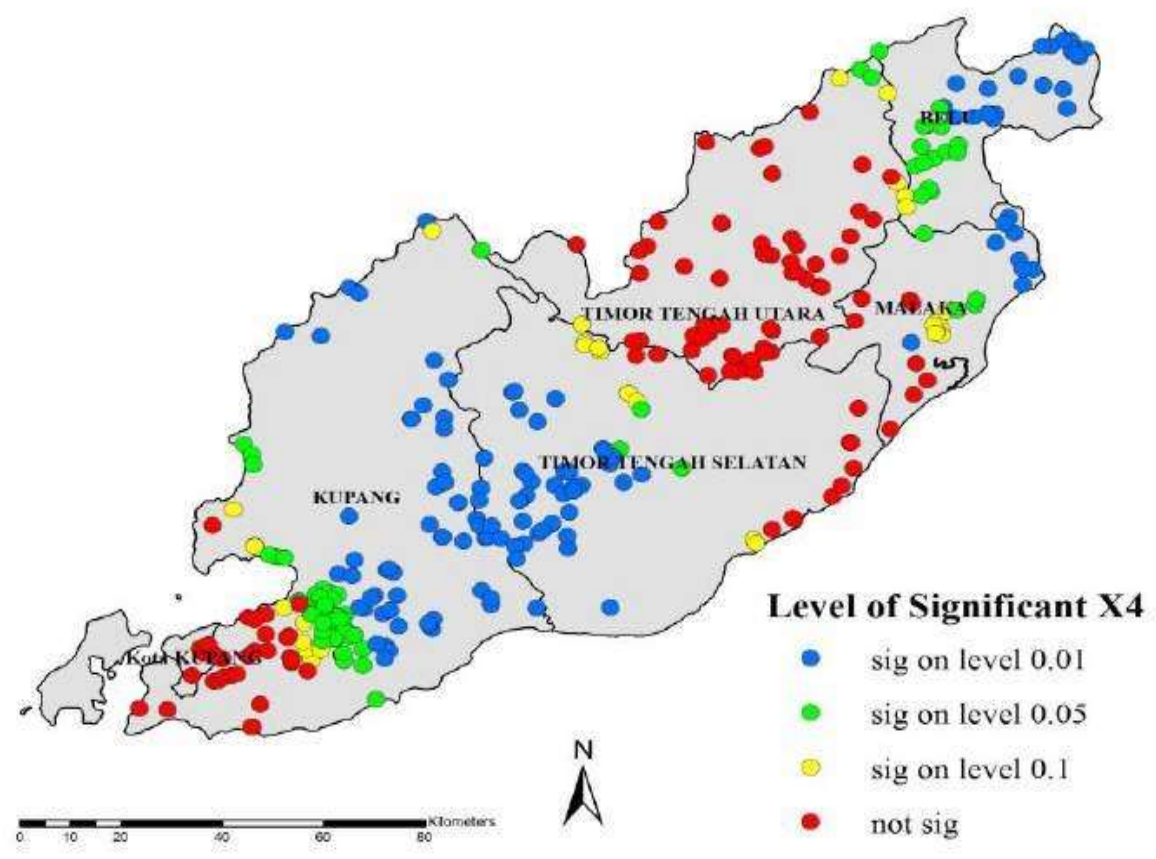

(3b)

Figure 3. (3a), (3b) The damage rate of headwork and the significance of relationship between damage rate of headwork and the performance of irrigation system

\subsection{Damage rate of primary canals}

The primary canal is one of the carrier buildings with a function of flowing water to secondary and tertiary canals. Primary canals are designed to be stronger than other irrigation canals, however, although primary irrigation canals are not along secondary irrigation canals the damage such as seepage, leakage along the primary canal are the most common. Therefore, the monitoring operation of irrigation water is needed to measure the distribution of irrigation water to find out the existence of shortages, seepage, and leakage which are the indication of damage caused disruption on the water distribution system. The success of the irrigation water distribution system is whether water is provided in accordance with the target of predetermined, adequate, reliable, efficient, and fair [1].

The damage rate of primary canals had a significant and negative effect on the performance of irrigation systems (Figure 4). This means that the reduced of the damage along with the increased performance of the irrigation system. These irrigation area group was found in TTU. Malaka and part TTS districts, covering 21.81 percent of the district/municipality irrigation area authority. 7.14 percent of the the provincial government authority and 20 percent of the the central government's. The results are in line with the study of [19] which stated that the distribution of irrigation water with poor canals condition is a major factor of low irrigation systems performance, so it is necessary to assess whether the irrigation network systems achieve targeted distribution goals. Bunganain [42] revealed that the overall damage of irrigation canals caused water loss and led tolow efficiency of irrigation. Likewise, the results of the study by [40] reported that the irrigation canals are priority aspect in determining the performance of irrigation systems in addition to aspects beside crop productivity, supporting facilities, operational labor, and WUA participation. The damage rate of primary canals had the lowest contribution to the performance of irrigation systems compared to the damage rate of secondary canals and drainage system. 


\section{International Journal of Current Science Research and Review}

ISSN: 2581-8341

Volume 04 Issue 06 June 2021

DOI: 10.47191/ijcsrr/V4-i6-15, Impact Factor: 5.825

IJCSRR@ 2021

www.ijjcsrr.org

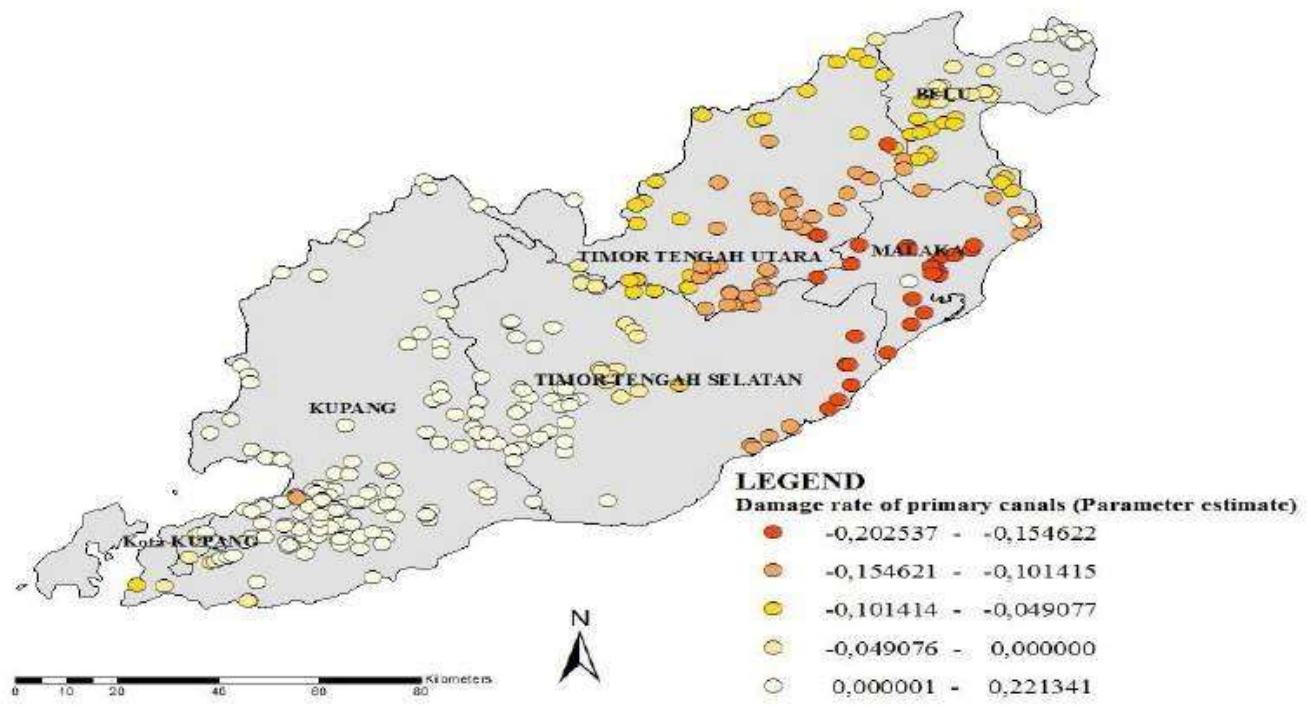

(4a)

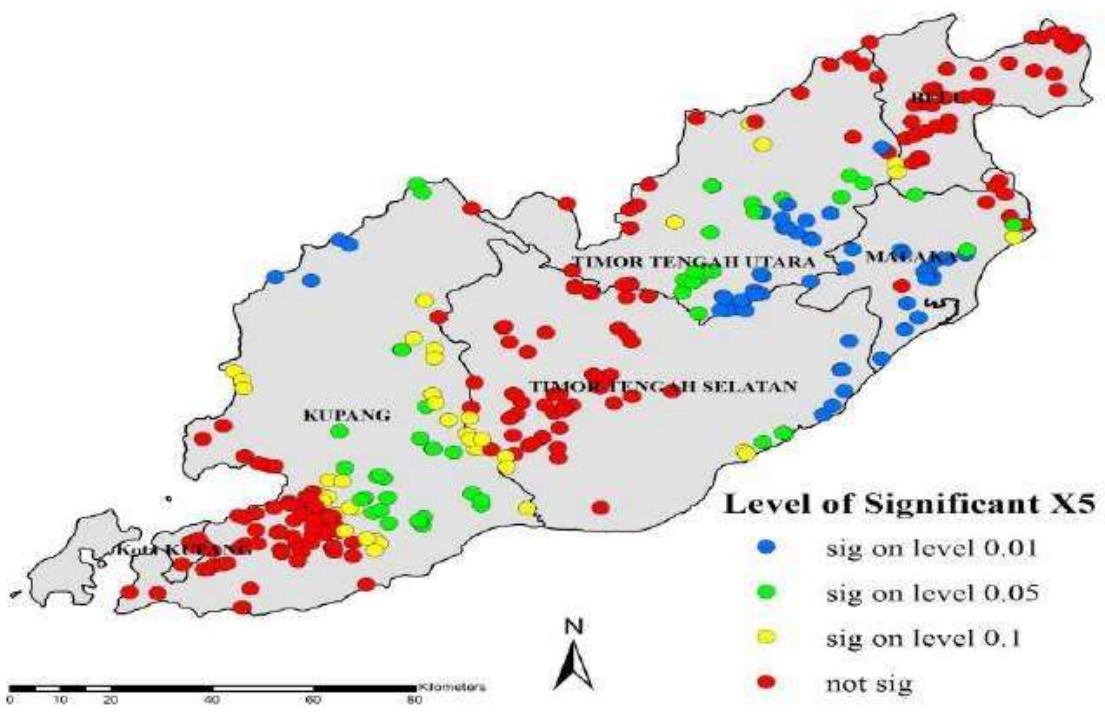

(4b)

Figure 4. (4a), (4b) The damage rate of primary canals and the significance of relationship between damage rate of primary canals and the performance of irrigation system

\subsection{Damage rate of secondary canals}

Secondary canals are building carry water from primary canals to tertiary canals. Based on the farmer's point of view, distribution of irrigation water needs to consider the timeliness, flow rate, and period or duration of irrigation water, so the role of irrigation canals' use is important for the sustainability of irrigated land.

Secondary canals need more attention because the canal length allows the greatest water loss during distribution, it is also one of the most important factors that cause uneven water distribution on farmers' land. The increased level of seepage loss along 


\section{International Journal of Current Science Research and Review}

ISSN: 2581-8341

Volume 04 Issue 06 June 2021

DOI: 10.47191/ijcsrr/V4-i6-15, Impact Factor: 5.825

IJCSRR@ 2021

www.ijcsrr.org

secondary canals affected the downstream farmers get the least water compared to those in the upstream due to the secondary irrigation network. The damage rate of secondary canals is a major cause of failure in the performance of the irrigation system with the greatest water loss. Thus, in the irrigation water distribution operating system, monitoring of water in the secondary canals should often be done because it can be a threat to crop production.

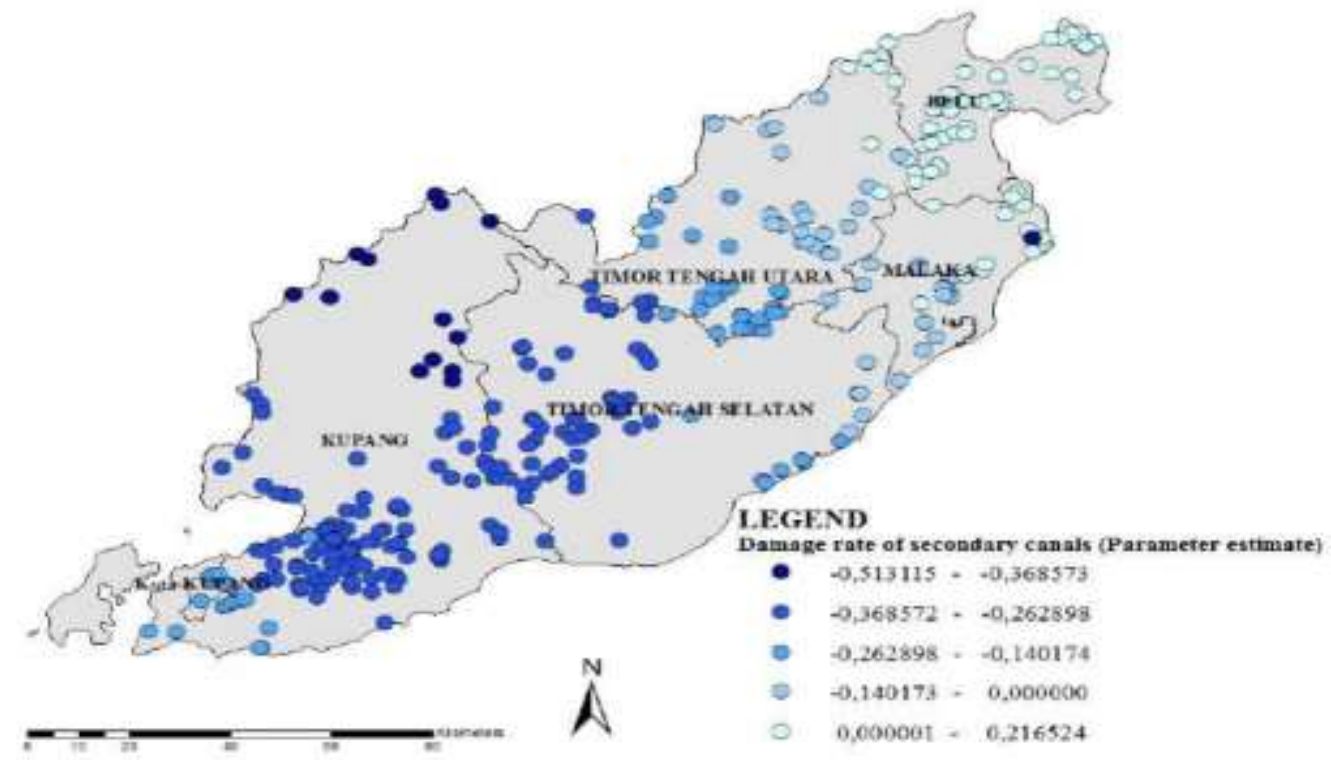

(5a)

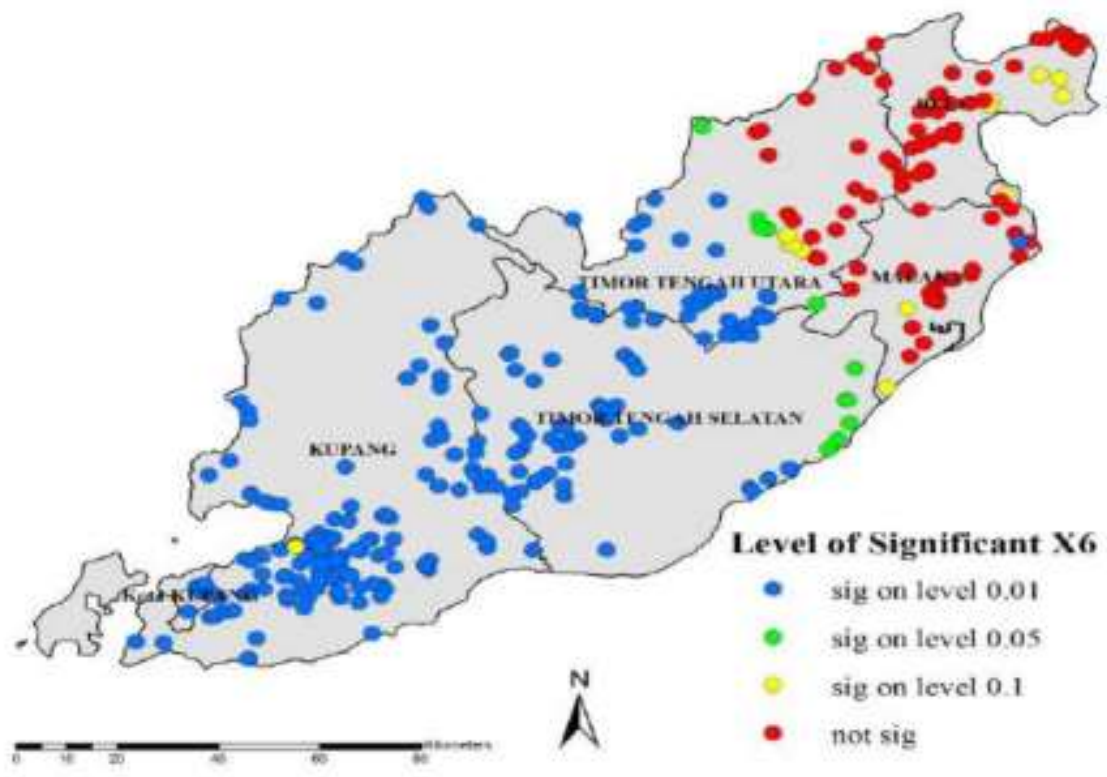

$(5 b)$

Figure 5. (5a), (5b) The damage rate of secondary canals and the significance of relationship between damage rate of secondary canals and the performance of irrigation system 


\section{International Journal of Current Science Research and Review}

ISSN: 2581-8341

Volume 04 Issue 06 June 2021

DOI: 10.47191/ijcsrr/V4-i6-15, Impact Factor: 5.825

IJCSRR@ 2021

www.ijcsrr.org

The damage rate of secondary canals had a significant effect and negative relationship to the performance of irrigation systems (Figure 5). The lower damage rate of secondary canals impacted the increasing performance of the irrigation system. These irrigation area group are from Kupang municipality, KupangDistrict. TTS, and TTUDistrict covering 75.39 percent of the irrigation area under district/municipality authority. 42.86 percent of irrigation areas under the authority of the provincial government and 60 percent of the irrigation area of the central government. This finding is in line with the results of research by $[19,42,40]$. Mangrio et al. [7] who focused on secondary canals stated that the reliability of water supply in secondary canals was very low due to high damage rate and lead the performance of irrigation systems to be poor performance category. The damage rate of secondary canals has the highest contribution of irrigation infrastructure groups affecting the performance of irrigation systems.

\subsection{Damage rate of drainage system}

Drainage systems are intended to remove excess water in the fields and canals. Excess water in paddy fields is discharged through drainage systems, while excess water in canals is discharged through spillway buildings. This drainage system includes quarterly, tertiary, secondary, and primary drainage system; these canals to drainage paddy fields and to remove excess rainwater and excess irrigation water. The excess water can also be used for other fields. The non-functioning of the drainage system can impact the inundation of plants in paddy fields that cause rot, or excess free irrigation water without being able to be utilized at all.

The damage rate of drainage system had a significant and negative effect on the performance of the irrigation system (Figure 6); the lower the damage rate, the better the performance of the irrigation system. This irrigation area group was found in TTU District. Belu District. Malaka District and parts of the TTS District covering 27.41 percent of the irrigation area of the District / Municipality authority. 50 percent of the irrigation area of the provincial authority and 40 percent of the irrigation under the authority of the central government. These results in line with [40], physical aspects of canals are priority aspects in determining the performance of irrigation systems in addition to aspects of crop productivity, supporting facilities, operational labor, and WUA participation.

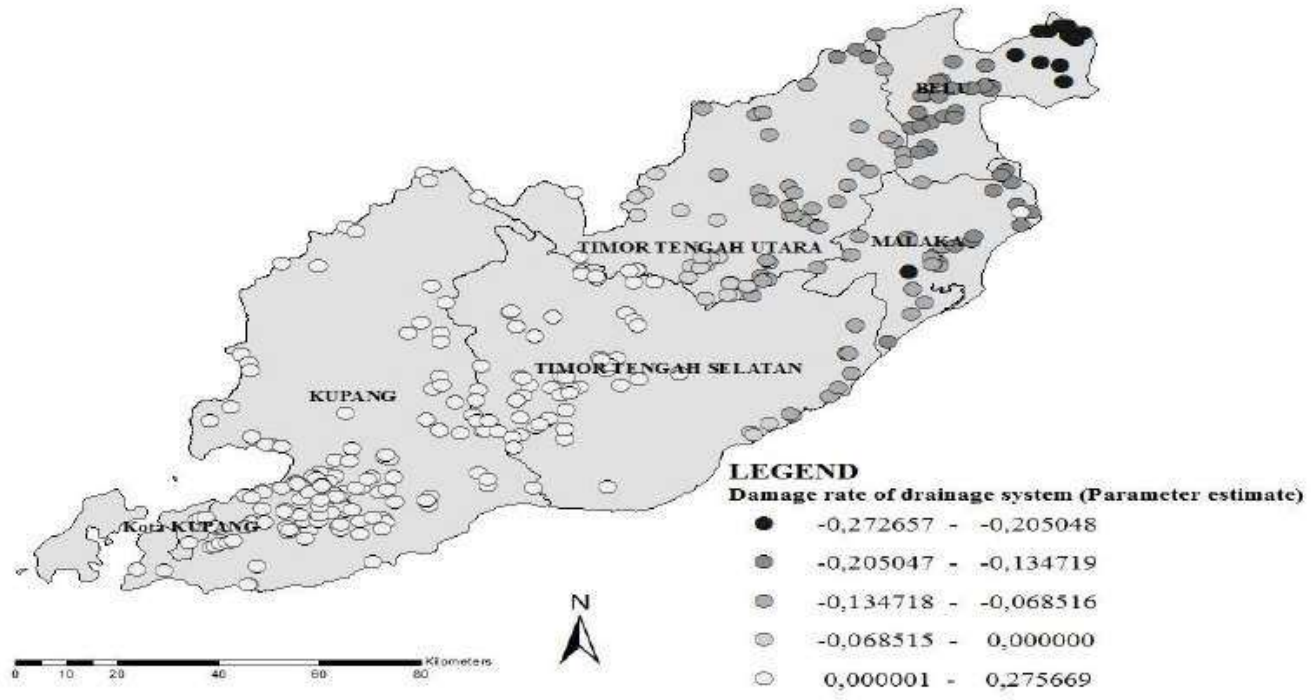

(6a) 


\section{International Journal of Current Science Research and Review}

ISSN: 2581-8341

Volume 04 Issue 06 June 2021

DOI: 10.47191/ijcsrr/V4-i6-15, Impact Factor: 5.825

IJCSRR@ 2021

www.ijcsrr.org

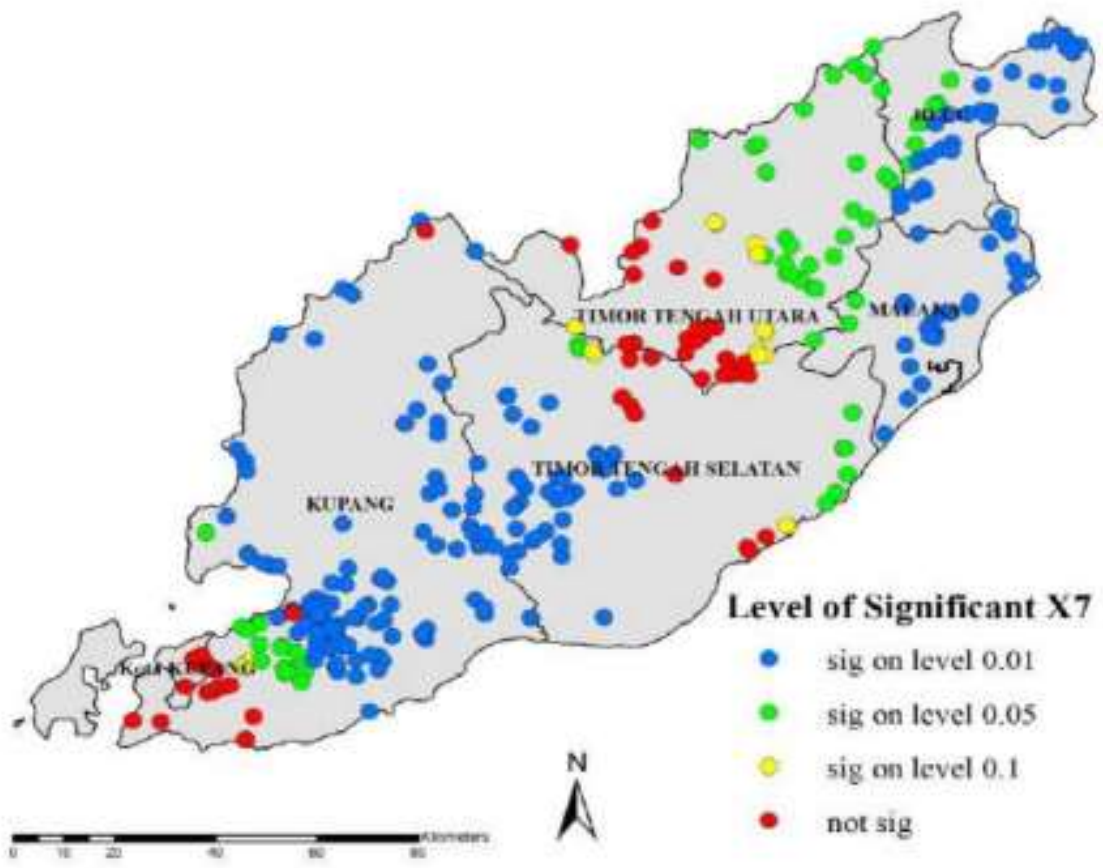

(6b)

Figure 6. (6a), (6b) The damage rate of drainage system and the significance of relationship between damage rate of drainage system and the performance of irrigation system

\subsection{Maintenance frequency of main system}

The continuity of the irrigation system requires maintenance of irrigation main system continuously with operating funds. Maintenance of buildings and canals is ideally continuous with frequency according to the standard of operation and maintenance to ensure the sustainability of irrigation infrastructure. The results revealed that the frequency of maintenance of main system (buildings and canals0 had a significant and positive effect on the performance of irrigation systems (Figure 7); indicating that the increase in the frequency of maintenance of the main system had an effect on improving the performance of irrigation systems.

The irrigation areas clustered in the TTS District, parts of Kupang District and TTU District, covering 34.58 percent of the irrigation area of the District / Municipality authority. 35.71 percent of the irrigation area of the provincial authority and 10 percent under the authority of the central government. TTS District is an area with an altitude of about 900 asl with a dry climate, hilly area, and the damage rate of infrastructure tends to be more quickly. These conditions caused decline performance of the irrigation system. The results of this study are in line with the research of [43], delayed canal maintenance will result in more damage and cause low canals performance. In addition, the results of the study of $[24,44]$ stated that insufficient or poor maintenance of the canals caused high damage rate of the canals and low irrigation system performance. The same study of poor maintenance and the ineffective control of irrigation practices has damaged many irrigation systems [45]. Frey and Rusch in [46] stated that the frequency of maintenance-monitoring in irrigation operations is crucial because it greatly affected the performance of irrigation systems. 


\section{International Journal of Current Science Research and Review}

ISSN: 2581-8341

Volume 04 Issue 06 June 2021

DOI: 10.47191/ijcsrr/V4-i6-15, Impact Factor: 5.825

IJCSRR@ 2021

www.ijjcsrr.org

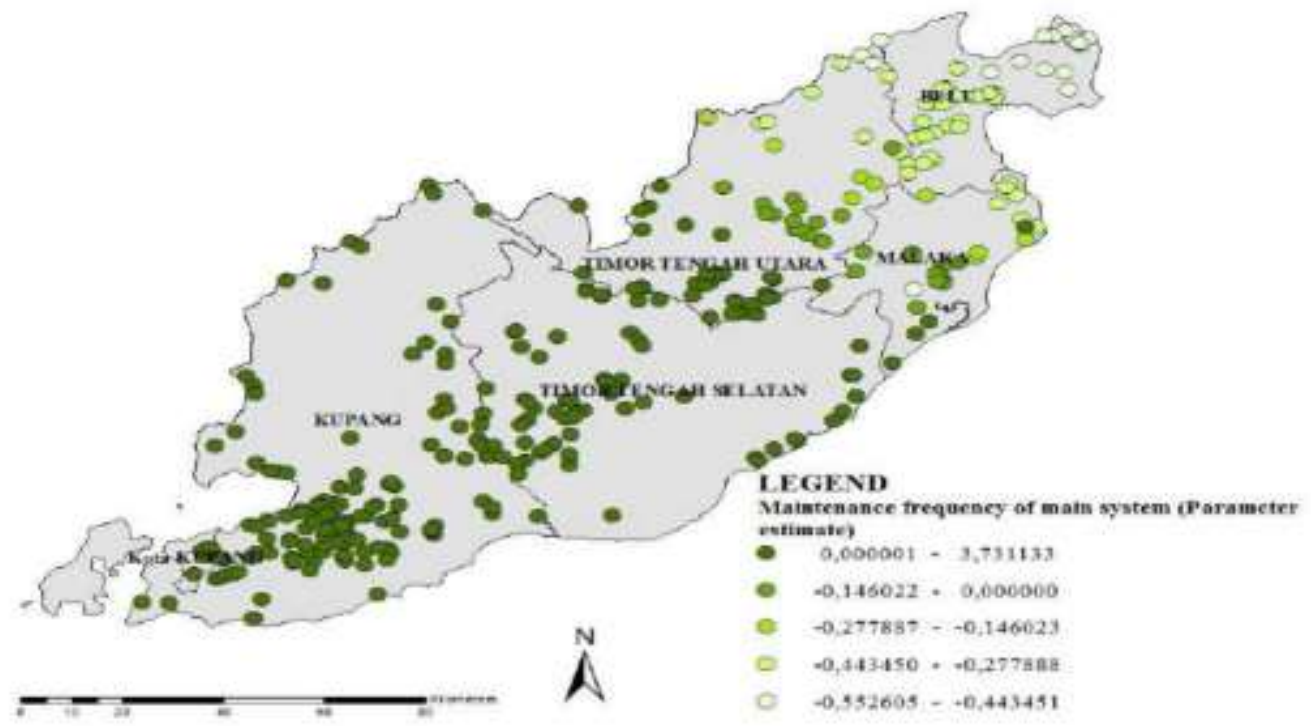

(7a)

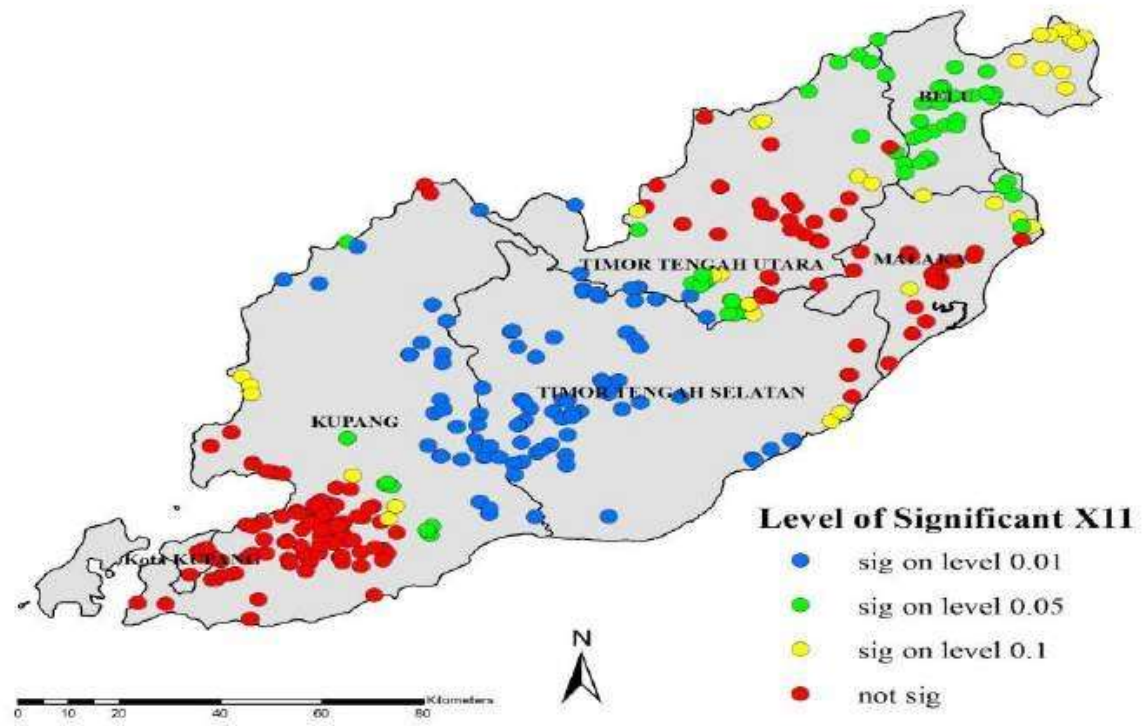

(7b)

Figure 7. (7a), (7b) Maintenance frequency of main system (headwork and canals) and significance of relationship between maintenance frequency of main system and the performance of irrigation system

\subsection{Authority of irrigation area district/municipality}

Institutional division of irrigation areas' authority, namely the authority of district/ municipality, showed significant and negative effect on the performance of irrigation systems. The negative relationship means that the irrigation area of the district/municipality authority shows a lower/worse performance of the irrigation system compared to other irrigation areas' authority (provincial and central government), all other things being equal (Figure 8). The entire irrigation area of the district/municipality authority (six district/municipality of Timor Island) significantly effectd the performance of irrigation systems. The results of this study on the performance of irrigation systems suggested the possible reduction of irrigation areas under the $605{ }^{*}$ Corresponding Author: Ida Nurwiana 


\section{International Journal of Current Science Research and Review}

ISSN: 2581-8341

Volume 04 Issue 06 June 2021

DOI: 10.47191/ijesrr/V4-i6-15, Impact Factor: 5.825

IJCSRR@ 2021

www.ijcsrr.org

district/municipality authority by rules rearrangement of the standard criteria for the irrigation area under the authority of the district/ municipality, so that the performance of the irrigation system is better.

Indriastuti and Muktiali [47] stated that institutional aspects are very important, as the condition of adequate resources does not guarantee the overall success of resource management when the institutional aspects are still weak. Lansing $[48,49,50]$ revealed that irrigation systems not only consisted of resources (water sources) and physical infrastructure (headworks and canals) but also actors who manage resources (farmers and irrigation labor) and government authority that regulate the actions and interactions of actors (irrigation system institution). An efficient irrigation system institution, reflected by the performance of a good irrigation system and vice versa.

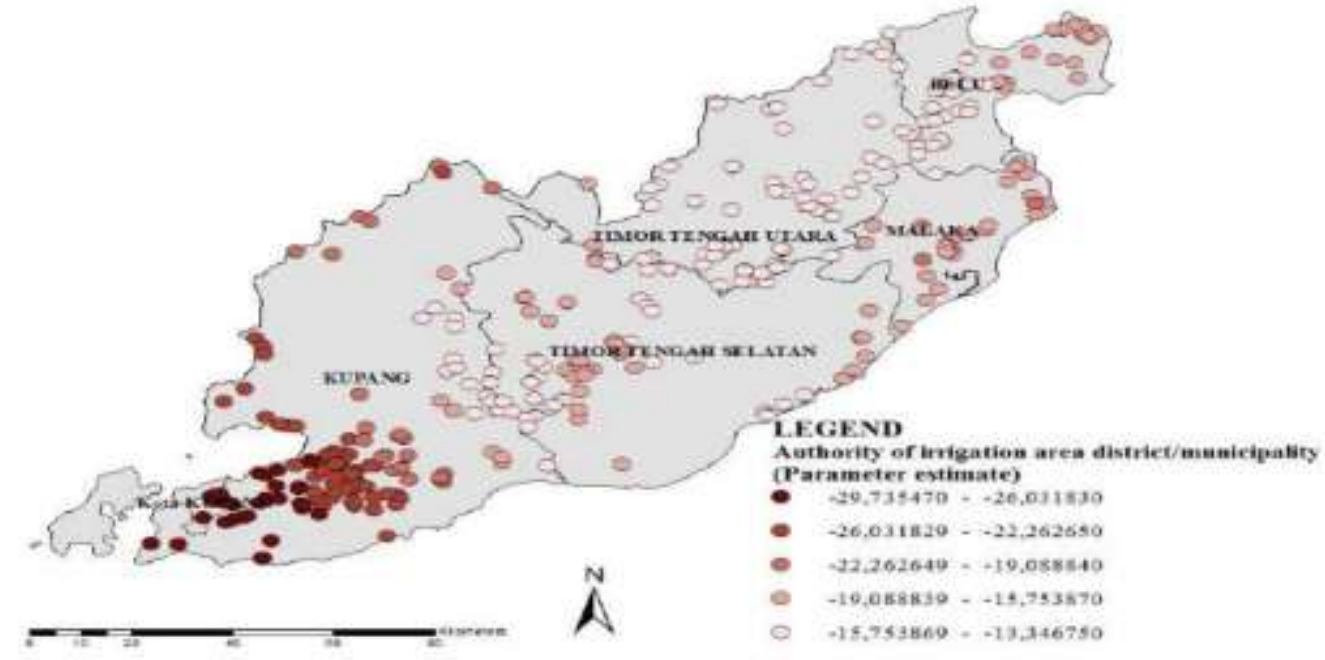

(8a)

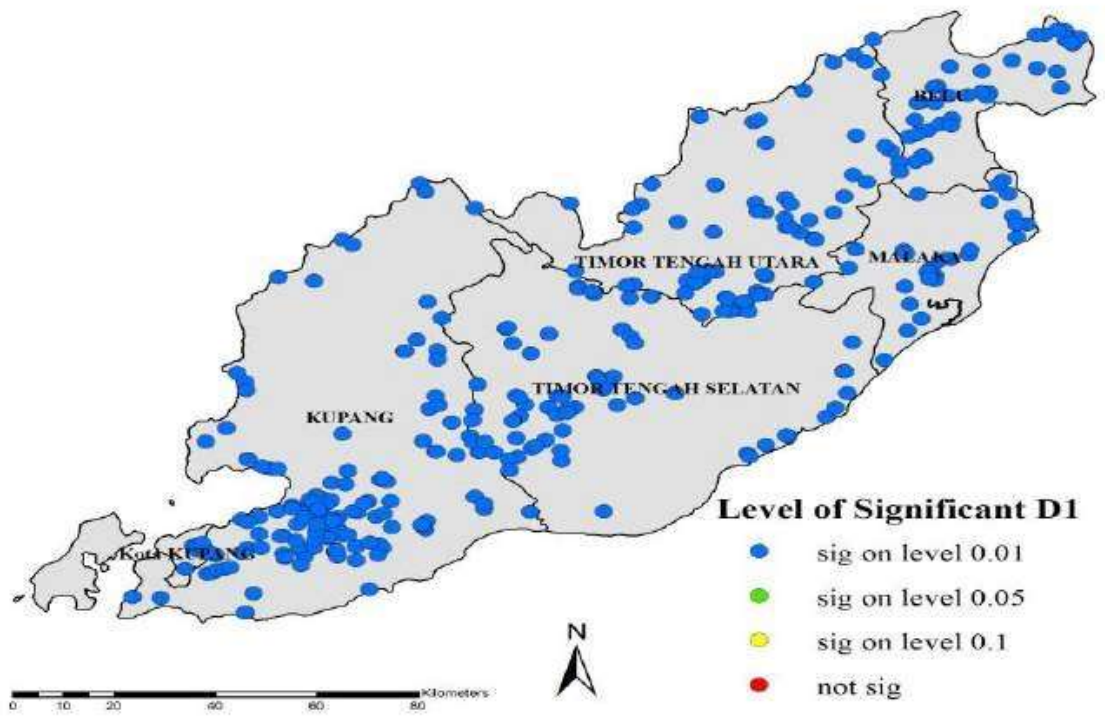

(8b)

Figure 8. (8a), (8b) Authority of irrigation area district/municipality and significance of the relationship between authority of irrigation area district/municipality and the performance of irrigation system. 


\section{International Journal of Current Science Research and Review}

ISSN: 2581-8341

Volume 04 Issue 06 June 2021

DOI: 10.47191/ijcsrr/V4-i6-15, Impact Factor: 5.825

IJCSRR@ 2021

www.ijesrr.org

\section{CONCLUSIONS}

The results of this study indicated that total cropping intensity had a significant effect and decreases the performance of irrigation area irrigation systems under the authority of district/municipality, province, and central governments. The higher rice productivity and the maintenance frequency of the main system (buildings and canals) would improve the performance of the irrigation system. The lower damage rate of headwork, primary canals, secondary canals, and drainage system would improve the performance of the irrigation system. The irrigation area under the district/municipality authority had a lower irrigation system performance compared to those under the authority of provincial and central governments.

This research is expected to be considered by the District/Municipality governments in Timor Island. NTT Province and Central government of the Republic of Indonesia in making policies on the handling of the performance of irrigation systems by adjusting the hydrogeological characteristics of dry areas so that policies become more effective and efficient. Policy can be realized in the different form of standard performance of irrigation systems regulation for dry region/insufficient water and wet region/excess water areas, and by rearrangement of standard total areas for irrigation region under the authority of the district/ municipality to increase the performance of irrigation system authorized by district/municipality.

\section{REFERENCES}

1. Molden, DJ., Gates TK., 1990. Performance measures for evaluation of irrigationwater delivery systems. Journal of Irrigation and Drainage Engineering 116(6):804-823.

2. Tang, S., 1992. Institutions and Collective Action: Self-Governance in Irrigation. San Francisco. California (US): ICS Press.

3. Benjamin, P., Lam, WF., Ostrom, E., Shivakotied, G., 1994. Institutions. incentives and irrigation in Nepal. Decentralization. Finance and Management Project Report. Associates in Rural Development. Inc. in Collaboration with Indiana University. Workshop in Political Theory and Policy.

4. Plusquellec, H., 2002. Is the daunting challenge of irrigation achievable?. Irrigation and Drainage. 51:185-198. doi:10.1002/ird.51.

5. Gorantiwar, SD., Smout I.K., 2005. Performance assessment of irrigation water management of heterogeneous irrigation schemes: a framework for evaluation. Irrigation and Drainage Systems. 19(1):1-36.

6. Balderama, OF., Bareng, J.L., R. Alejo, L.A., 2014. Benchmarking for performance assessment of irrigation schemes: the case of national irrigation systems and small water impounding projects in Cagayan River Basin. International Conference of Agricultural Engineering. Zurich 6-10 July.

7. Mangrio, M.A., Mirjat, MS., Li, J.H., Chandio, AS., 2014. Performance evaluation of irrigation system at secondary canal level. Pakistan Journal of Agriculture Agricultural Engineering Veterinary Sciences. 30(2):216-228.

8. Abernethy, C.L. 1986. Performance Measurement in Canal Water Management: ADiscussion. ODI-IIMI Irrigation Management Network Paper 86/2d. London (GB): Overseas Development Institute.

9. Bos, M.G., Murray-Rust, H.D. Merrey, D.J., Johnson, H.G., Snellen, W.B., 1993. Methodologies for assessing performance of irrigation and drainage management. Irrigation and Drainage Systems. 7:231-261. Springer.

10. Molden, D.J., Sakthivadivel, R., Perry, C.J., de Fraiture, C., Kloezen, W.H., 1998. Indicators for Comparing Performance of Irrigated Agricultural Systems. Research Report 20. Colombo. Sri Lanka: International Water Management Institute/IWMI.

11. Kloezen, W.H. Garces-Resrepo, C., 1998. Assessing Irrigation Performance with Comparative Indicators: The Case of the Alto Rio Lerma Irrigation District. Mexico. Colombo. Sri Lanka: International Water Management Institute/IWMI.

12. Murray-Rust DH. Snellen. 1993. Irrigation system performance assessment and diagnosis. International Irrigation Management Institute. Colombo.Sri Lanka.

13. Manaze, AS., 2015. Performance assessment irrigation schemes according to comparative indicators: a case study of ShinaHamusit and Selamko. Ethiopia. International Journal of Scientific and Research Publications. 5(12):451-460. December 2015.451 ISSN 2250-3153. 


\section{International Journal of Current Science Research and Review}

ISSN: 2581-8341

Volume 04 Issue 06 June 2021

DOI: 10.47191/ijcsrr/V4-i6-15, Impact Factor: 5.825

IJCSRR@ 2021

www.ijcsrr.org

14. Ahlawat, V., Renu. 2016., Regional disparity in cropping intensity and relative impact of irrigation in Haryana. IOSR Journal of Business and Management (IOSR-JBM). 18(9):41-45. doi:10.9790/487X-1809034145. ISSN: 2278-487X. pISSN: 2319-7668.

15. Tilahun, H., Teklu, E., Michael, M., Fitsum, H., Awulachew, S., 2011. Comparative performance of irrigated and rainfed agriculture in Ethiopia. World Applied Sciences Journal. 14(2):235-244. ISSN 1818-4952.

16. Sayin, B., Karaman, S.Yilmaz, I., Çelikyurt, M.A., 2013. Assessment of the performance of participatory irrigation management in Antalya. Turkey. Water Policy. 15:269-280. doi:10.2166/wp.2012.133.

17. Koc, C., Ozdemir, K., Erdem., AK., 2006. Performance of water user associations in the management operation and maintenance of Great Menders Basin Irrigation Schemes. Journal of Applied Sciences. 69(1): 90-93.

18. Omid, MH., Akbari, M., Zarafshani, K., Eskandari, G.H., Fami, HS., 2012. Factors influencing the success of water user associations in Iran: a case of Moqan. Tajan. and Varamin. Journal of Agricultural Science and Technology. 14(1):2736.

19. Yercan, M., Atis, E., Salali, H.E. 2009. Assessing irrigation performance in the Gediz river basin of Turkey: water user associations versus cooperatives. Irrigation Science. 27(2009):263-270. doi:10.1007/s00271-008-0142-z.

20. Yami, M., 2013. Sustaining participation in irrigation systems of Ethiopia: what have we learned about water user associations?. Water Policy. 15 (2013):961-984. doi:10.2166/wp.2013.031.

21. Mohan, R.J., 1986. Management of gravity flow irrigation systems. In: K.C Nobe and R.K Sampath (eds.). Irrigation Management in Developing Countries: Current Issues and Approaches. Colorado (US): Westview Press. pp. 95-116.

22. Saleth, R.M., Dinar, A., 1999. Evaluating Water Institutions and Water Sector Performance. World Bank Technical Paper No: 447. Washington. DC (US): World Bank.

23. Saleth, R.M., Dinar A. 2003. Institutional linkages. transaction costs. and water institutional reforms: analytical approaches and cross-country evidences. Chapter Prepared for Discussion and Review in the Environmental Economics Task Force Meeting. Columbia University. New York. October 10-11. 2003.

24. Gyasi, K.O., Engel, S., Frohberg, K., 2006. What Determines the Success of Community-Based Institutions for Irrigation Management? ZEF Policy Brief. No.5. Ghana.

25. Ward, F.A., 2010. Financing irrigation water management and infrastructure: a review. Water Resources Development. 26(3):321-349.

26. Qtaishat, T., 2013. Impact of water reallocation on the economy in the Fertile Crescent. Water Resources Management. (2013)27:3765-3774. doi: 10.1007/s11269-013-0379-z. Springer.

27. Lam, W.F., Chiu, C.Y., 2016. Institutional nesting and robustness of selfgovernance: the adaptation of irrigation systems in Taiwan. International Journal of the Commons. 10(2016)(2):953-981. doi:10.18352/ijc.638.

28. Anselin, L., Rey, S.J., 2010. Perspectives on spatial data analysis. In Perspectives on Spatial Data Analysis. pp. 1-20. Springer Berlin Heidelberg.

29. Fotheringham, A.S., Brundson, C., Charlton, M., 2002. Geographically Weighted Regression: The Analysis of Spatially Varying Relationships. UK: John Wiley and Sons. Ltd.

30. Brunsdon, C., Clatchey, J.M., Unwin, D., 2001. Spatial variations in the average rainfall-altitude relationships in Great Britain: an approach using geographically weighted regression. International Journal of Climatology. 21(4):455-466.

31. Calvo, C., Escolar, M., 2003. The local voter: a geographically weighted approach to ecological inference. American Journal of Political Science. 47(1):189-204.

32. Longley, P.A., Tobon, C., 2004. Spatial dependence and heterogeneity in patterns of hardship: an intra-urban analysis. Annals of the Association of American Geographers. 94(3):503-519. Taylor \& Francis.

33. Mennis, J., Jordan, L., 2005. The distribution of environmental equity: exploring spatial nonstationarity in multivariate models of air toxic releases. Annals of the Association of American Geographers. 95(2):249-268.

34. Mennis, J., 2006. Mapping the results of geographically weighted regression. The Cartographic Journal. 43(2):171-179.

35. Propastin, P., Kappas, M., Erasmi, S., 2007. Application of geographically weighted regression to investigate the impact of scale on prediction uncertainty by modeling relationships between vegetation and climate. International Journal of Spatial Data Infrastructures Research. 3:73-94. 


\section{International Journal of Current Science Research and Review}

ISSN: 2581-8341

Volume 04 Issue 06 June 2021

DOI: 10.47191/ijcsrr/V4-i6-15, Impact Factor: 5.825

IJCSRR@ 2021

www.ijcsrr.org

36. Sharma, V., Irmak, A., Kabenge, I., Irmak, S., 2011. Application of GIS and GWR to evaluate the spatial non stationarity relationships between precipitation vs. irrigated and rainfed maize and soybean yields. American Society of Agricultural and Biological Engineers. 54 (3): 953-972. ISSN 2151-0032.

37. Fu, Q., Liu, W., Cui, S., Li, T., Liu, D. 2017. Geostatistical analysis of factors affecting irrigation water use efficiency on the Sanjiang Plan. The American Society of Agricultural and Biological Engineers. St. Joseph. Michigan. 60(2):431-438. doi: 10.13031/trans.11984.

38. Gwarda, K.L., 2018. Geographically Weighted Regression in the Analysis of Unemployment in Poland. International Journal ofGeo-Information. 7(17):1-16 doi:10.3390/ijgi7010017.

39. Lee, J., Wong, D.W.S., 2001. Statistical Analysis with Arcview GIS. New York (US): John Wiley and Sons. ISBN:9780471437765.

40. Kusuma OPU. Rispiningtati. Sayekti RW. 2012. Priority scale study on canals performance improvement in Bodor irrigation area, Nganjuk District. Jurnal Teknik Pengairan. 3(1):61-70.

41. Borgia, C., Bolaños, M.G., Li,T., Macpherson, H.G., Comas, J., Connor, D., Mateos, L., 2013. Benchmarking for performance assessment of small and large irrigation schemes along the Senegal Valley in Mauritania. Agricultural Water Management. 121:19-26. doi:10.1016/j.agwat.2013.01.002. Elsevier.

42. Bunganaen, W., 2011. Efficiency analysis and water loss in the main network of irrigation areas, Air Sagu. Jurnal Teknik Sipil. 1(1). Universitas Petra Surabaya.Indonesia.

43. Kisnanto, S., Hadiani R.R.R. Ikhsan, C., 2017. Infrastructure performance of irrigation canal to irrigation efficiency of irrigation area of Candi Limo in Mojokerto District. International Conference on Advanced Materials for Better Future 2017. IOP Conf. Series: Materials Science and Engineering 333(2018) 012096. doi:10.1088/1757-899X/333/1/012096.

44. Bolaños, G., Borgia, M., Poblador, C., Dia, N., Seyid, O.M.V., Mateos, L. 2011. Performance assessment of small irrigation schemes along the Mauritanian banks of the Senegal River. Agricultural Water Management. 98(7):1141-1152. doi:10.1016/j.agwat.2011.02.008. Elsevier.

45. Nhundu, K., Mushunje, A., Zhou, L., Aghdasi, F., 2015. Institutional determinants of farmer participation in irrigation development post "fast-track" land reform program in Zimbabwe. Journal of Agricultural Biotechnology and Sustainable Development. 7(2):9-18. doi:10.5897/JABSD09.038.

46. Frey, U.J., Villamayor-Tomas, S., Theesfeld, I., 2016. A continuum of governance regimes: a new perspective on comanagement in irrigation systems. Environmental Science \& Policy. 66:73-81. doi:10.1016/j.envsci.2016.08.008. Elsevier.

47. Indriastuti, W., Muktiali, M., 2015. Commons dilemma in the management of Kapiler irrigation areas. Klaten District. Jurnal Wilayah dan Lingkungan. 3(2):105-120. doi:10.14710/jw1.3.2.

48. Lansing, J., 1991. Priests and Programmers: Technologies of Power in the Engineered Landscape of Bali. Princeton. NJ: Princeton University Press.

49. Miller, J., Page, S., 2007. Complex Adaptive Systems. Princeton. NJ (US): Princeton University Press.

50. Mitchell, M., 2009. Complexity: A Guided Tour. New York (US): Oxford University Press.

Cite this Article: Ida Nurwiana, Akhmad Fauzi, Ernan Rustiadi, Bambang Juanda (2021). Institutional Performance of Irrigation System in Spatial Dimensions in Semi-Arid Region Timor Island East Nusa Tenggara. International Journal of Current Science Research and Review, 4(6), 590-609 